\title{
Implementasi Pendidikan Multikultural Dalam Membentuk Moral Knowing Siswa Tentang Narkotika
}

\section{Multicultural Education Implementation In Forming Moral Knowing Of Students On Narcotics}

\author{
Ika Chastanti ${ }^{*}$, Indra Kumalasari Munthe ${ }^{2}$ \\ ${ }^{1}$ Pendidikan Biologi - STKIP Labuhan Batu, Sumatera Utara \\ ${ }^{2}$ Ilmu Hukum - STIH Labuhan Batu, Sumatera Utara \\ *Korespondensi: Chastanti.ika@gmail.com
}

\begin{abstract}
Abstrak
Penyalahguna narkotika di kalangan siswa sudah semakin banyak. Indonesia menjadi Negara darurat narkotika. Telah banyak ditemukan siswa yang positif mengkonsumsi narkoba jenis I yaitu Ganja. Implementasi pendidikan multicultural lintas budaya yaitu Pencegahan Pemberantasan Penyalahgunaan dan Peredaran Gelap Narkotika (P4GN) perlu dilakukan untuk membantu mengurangi penyalahguna narkotika. Selain P4GN perlu ditanamkan moral knowing siswa tentang narkotika yang bisa dilakukan di sekolah. Metode penelitian ini kualitatif dengan teknik purposive sampling. Sanpel dalam penelitian ini adalah Kepala Sekolah, Guru, Orang tua dan siswa yang positif mengkonsumsi narkotika. Teknik pengumpulan data dilakukan dengan wawancara mendalam (In-depth Interview) dan pemberian angket kepada siswa. Analisis data menggunakan Miles dan Huberman. Hasil penelitian menunjukkan bahwa pendidikan multicultural belum dilaksanakan sepenuhnya oleh sekolah karena sekolah belum memahami konsep pendidikan multicultural sehingga moral knowing siswa tentang narkotika masih tergolong rendah.
\end{abstract}

Kata Kunci : Moral Knowing, Pendidikan Multikultural, P4GN

\begin{abstract}
Drug abusers among students are increasing. Indonesia is a state of narcotics emergency. It has been found that many positive students consume type I drugs, namely marijuana. Implementation of cross-cultural multicultural education namely Prevention of Eradicating Narcotics Abuse and Illicit Circulation (P4GN) needs to be done to help reduce narcotics abusers. In addition to P4GN students need to instill Moral Knowing about narcotics that can be done at school. This research method is descriptive qualitative with purposive sampling sampling technique. Headmasters, teachers, parents, and students whose consume narcotics as samples. Data collections by In-depth Interviewand questionnaire for students. Data was analysed by Miles and Huberman's Model. The results revealed that multicultural education had not been fully implemented by the school because the school did not yet understand the concept of multicultural education so that the moral knowing of students about narcotics was still low.
\end{abstract}

Keywords: Implementation P4GN, Moral Knowing, Multicultural Education

\section{PENDAHULUAN}

Karakter bangsa merupakan aspek penting dalam kualitas SDM karena kualitas bangsa menentukan kemajuan suatu bangsa. Ada sepuluh tanda-tanda zaman yang harus diwaspadai karena jika tanda ini sudah ada, berarti sebuah bangsa sedang menuju jurang kehancuran. Tanda-tanda yang dimaksud adalah (1) meningkatnya kekerasan di kalangan remaja, (2) Penggunaan bahasa dan kata-kata yang buruk, (3) Pengaruh peer-grup yang kuat dalam tindak kekerasan, (4) meningkatnya perilaku merusak diri, seperti penggunaan 
narkoba,alkohol, dan seks bebas, (5) menurunnya etos kerja, (6) semakin rendahnya rasa hormat kepada orang tua dan guru (Lickona dalam Chastanti dan Munthe, 2018).

Perilaku merusak diri yang banyak terjadi saat ini adalah penggunaan narkoba di kalangan siswa. Berdasarkan data dari Badan Narkotika Nasional (BNN), pengguna narkoba tahun 2013 sudah mencapai 3,8 juta. (Rudi, 2013).Temuan hasil survei menunjukkan bahwa ganja adalah jenis narkoba yang paling banyak disalahgunakan dalam setahun terakhir (BNN, 2011).

Dampak penyalahgunaan narkoba salah satunya adalah menurunnya prestasi akademik di sekolah. Indikasi ini didukung oleh fakta berikut: hanya $24 \%$ dari penyalahguna yang nilainya diatas rata-rata kelas, bandingkan yang bukan penyalahguna 37\%; ada 11\% penyalahguna yang nilainya dibawah rata-rata kelas, bandingkan yang bukan penyalahguna hanya 5\%; fakta terakhir ada 1 dari 4 penyalahguna yang pernah tidak naik kelas (24\%), bandingkan dengan bukan penyalahguna hanya 10\%. Dampak sosial yaitu (1) terjadinya gangguan mental emosional akan mengganggu fungsinya sebagai anggota masyarakat; (2) bertindak keliru yang menyebabkan dipecat dari pekerjaan; (3) hubungan dengan keluarga dan kawan dekat semakin renggang; (4) terjadinya anti sosial, asusila, dan dikucilkan dari lingkungan (BNN, 2011). Keadaan ini menandakan bahwa pembelajaran yang didapatkan siswa di sekolah ternyata tidak berdampak pada perilaku siswa. Hal ini terjadi karena proses pembelajaran hanya mengajarkan pendidikan moral sebatas teks dan disebabkan oleh beberapa faktor diantaranya yaitu lingkungan, proses pembelajaran dan perangkat pembelajaran yang digunakan (Zubaedi, 2011).

Pendekatan hukum tidak akan pernah efektif dalam mencegah penyalahgunaan narkotika. Test urine dilakukan, hasilnya positif berarti yang bersangkutan terindikasi mengkonsumsi narkotika, kemudian diambil tindakan hukum yang memberikan efek jera tetapi tindakan hukum ini belum mampu menyelesaikan masalah atau masyarakat bebas dari penyalahgunaan narkotika. Berperilaku baik karena alasan mematuhi dan/atau takut dihukum menunjukkan seseorang rendah moralnya (Aswandi, 2017).

Pendidikan multicultural merupakan proses yang tujuan utamanya adalah mengubah structural sosial masyarakat melalui pengubahan kultur sekolah.Implementasi pendidikan multicultural mampu mengubah struktural sosial masyarakat melalui pengubahan kultur sekolah yang diisi oleh beragam etnis maupun kelas sosial. Implementasi Program Pencegahan Pemberantasan Penyalahgunaan dan Peredaran Gelap Narkotika (P4GN) 
merupakan salah satu pendidikan multicultural lintas budaya. Sekolah memiliki tanggung jawab moral untuk mendidik siswa menjadi pintar dan memiliki karakter (Aswandi, 2017).

Moral knowing merupakan hal penting untuk diajarkan. Moral knowing ini terdiri dari enam hal yaitu (1) moral awareness (kesadaran moral), (2) knowing moral values (mengetahui nilai-nilai moral), (3) perspective taking, (4) moral reasoning, (5) Decision making, (6) self knowlegde. Moral knowing siswa perlu dibentuk agar siswa memiliki bekal pengetahuan sehingga siswa dapat menentukan tindakan yang benar jika dirayu/dibujuk orang lain untuk mengkonsumsi narkotika (Muslich, 2011).

Tugas sekolah tidak hanya mengajar, tetapi juga mendidik sehingga siswa tidak hanya memiliki kemampuan kognitif tetapi juga memiliki karakter yang baik. Pendidikan karakter bukan hanya sekedar mengajarkan mana yang benar dan mana yang salah, akan tetapi lebih dari itu pendidikan karakter adalah usaha menanamkan kebiasaan-kebiasaan yang baik (habituation) sehingga peserta didik mampu bersikap dan bertindak berdasarkan nilai-nilai yang telah menjadi kepribadiannya (Kemendiknas dalam Chastanti, 2018). Tujuan penelitian ini adalah untuk mengetahui penerapan pendidikan multicultural di sekolah dalam meningkatkan Moral Knowing siswa tentang narkotika.

\section{METODE PENELITIAN}

Artikel ini merupakan hasil penelitian kualitatif dengan melakukan studi kasus ke sekolah. Sampel dalam penelitian ini adalah Kepala Sekolah, Guru, Orang tua dan siswa yang positif mengkonsumsi narkotika golongan I yaitu Ganja. Teknik pengambilan data dilakukan dengan In-depth Interview (wawancara mendalam), dan kuesioner tentang Moral Knowing sehingga penelitian ini diarahkan untuk memberikan penjelasan dan gambaran mengenai implementasi pendidikan multicultural dalam membentuk Moral Knowingsiswa. Teknik analisis data dilakukan secara kualitatif dengan menggunakan model Miles dan Huberman. Model ini dilakukan dalam 3 tahap: (1) Reduksi data yaitu (a) meringkaskan data kontak langsung dengan orang, kejadian dan situasi di lokasi penelitian, (b) pengkodean, (c) pembuatan catatan objetif, (d) membuat catatan reflektif, (e) membuat catatan marginal, (f) penyimpana data, (g) pembuatan memo, (h) analisis antarlokasi, dan (i) pembuatan ringkasan sementara antar lokasi. Tahap (2) Display Data dengan menyusun teks naratif, Tahap (3) Verifikasi yaitu tahap penarikan kesimpulan. 


\section{HASIL DAN PEMBAHASAN}

Hasil wawancara mendalam (In-depth Interview)yang dilakukan kepada kepala sekolah dan wakil kepala sekolah diperoleh bahwa pendidikan multiculturalbelum dilaksanakan bahkan sekolah tidak mengetahui mengenai pendidikan multicultural. Siswa yang menjadi penyalahguna narkotika golongan I yaitu ganja tidak mendapatkan bimbingan konseling dari sekolah. Sekolah meminta siswa untuk tidak sekolah lagi, sehingga banyak siswa yang pindah ke sekolah lain dan masih ada 3 siswa yang tetap melanjutkan pendidikan di sekolah tersebut karena akan menghadapi Ujian Nasional.

Siswa yang melanjutkan pendidikan mendapatkan perlakukan tidak baik dari pihak sekolah. Siswa sering dipukul oleh guru dan siswa tersebut tidak diperbolehkan bergabung dengan siswa lainnya karena mereka diberikan ruangan khusus. Dari kasus ini dapat dilihat bahwa pendidikan multicultural belum sepenuhnya dilaksanakan oleh sekolah sehingga banyak siswa yang menjadi penyalahguna narkotika.

\section{Narkotika}

Hasil penelitian penyalahgunaan dan peredaran gelap narkoba pada kelompok pelajar/mahasiswa di Indonesia menunjukkan terjadinya peningkatan angka prevalensi yang cukup tinggi yaitu dari 5,8\% pada tahun 2003 menjadi 8,3\% pada tahun 2006 (BNN, 2011). Pemakaian narkoba pada siswa umumnya terjadi karena masa remaja merupakan masa pencarian jati diri sehingga muda bersosialisasi dengan individu lainnya dan biasanya remaja belum memiliki pemikiran yang matang sehingga mudah dipengaruhi untuk menggunakan narkoba.

Faktor yang menyebabkan remaja melakukan penyalahgunaan narkoba adalah sebagai berikut: Ajakan, bujukan dan iming-iming teman atau anggota kelompok sebaya. Cenderung memiliki gangguan jiwa seperti kecemasan, obsesi (memikirkan sesuatu secara berulangulang), apatis, menarik diri dalam pergaulan, depresi, kurang mampu menghadapi stres, atau hiperaktif. Suka berpetualang, mencari sensasi, melakukan hal-hal yang mengandung resiko bahaya yang berlebihan. Ketidak tahuan akan bahaya narkoba atau tidak memikirkan akan bahaya narkoba. Orang tua tidak acuh dan tidak mengadakan pengawasan terhadap anaknya. Tidak ada perhatian, kehangatan, kasih sayang dalam keluarga (Rauf, 2012).

Ancaman pidana bagi penyalahguna narkotika golongan I ini terdapat dalam Pasal 127 UU Narkotika. Proses hukum untuk membuktikan apakah anak memang merupakan 
penyalahguna ganja atau korban penyalahgunaan ganja. Jika dapat dibuktikan atau terbukti bahwa anak sebagai korban maka wajib menjalani rehabilitasi medis dan rehabilitasi sosial. Ancaman pidana penjara bagi anak yang melakukan tindak pidana adalah setengah dari maksimum ancaman pidana penjara bagi orang yang sudah dewasa sebagaimana yang telah diatur dalam Pasal 81 ayat (2) Undang-Undang Nomor 11 Tahun 2012 Tentang Sistem Peradilan Pidana Anak (Aswandi, 2017).

\section{Pendidikan Multicultural di Sekolah}

Pendidikan multicultural akan tercipta bila semua pihak senantiasa menjunjung tinggi nilai-nilai, keyakinan, heterogenitas, dan keragaman, apapun aspeknya dalam masyarakat. Pendidikan multicultural belum sepenuhnya diterapkan di sekolah karena masih minimnya pengetahuan sekolah mengenai pendidikan multicultural, terutama dalam penanganan narkotika di sekolah. Sekolah melakukan pembiaran terhadap siswa yang menjadi penyalahguna narkotika dan seolah lepas tangan terhadap siswa.

Salah satu pendidikan multiculturalyang bisa diterapkan di sekolah untuk tindakan preventif narkotika di kalangan siswa yaitu dengan Program Pencegahan Pemberantasan Penyalahgunaan dan Peredaran Gelap Narkotika (P4GN) (Sholihah, 2013). Penanggulangan narkoba tidak terlepas dari upaya pencegahan dan pemberantasan. Merujuk pada undangundang narkotika no 35 tahun 2009 pada Bab X, Pembinaan dan Pengawasan, pasal 60 ayat 2 tentang mencegah penyalahgunaan Narkotika, poin c yang menyatakan bahwa dibuatnya UU Narkotika untuk dapat mencegah generasi muda dan anak usia sekolah dalam penyalahgunaan Narkotika, termasuk dengan memasukkan pendidikan yang berkaitan dengan Narkotika dalam kurikulum sekolah dasar sampai lanjutan atas (Wulandari, 2016).

Implementasi P4GN mengadopsi pendidikan lintas budaya, yakni: Pendidikan multikultural merupakan proses yang tujuan utamanya adalah mengubah struktural sosial masyarakat melalui pengubahan kultur sekolah yang diisi oleh beragam etnis maupun kelas sosial meliputi lima dimensi dan diantara dimensi-dimensi tersebut ada yang dapat diimplementasikan: (a) Content Integration. berkenaan dengan upaya guru memasukkan informasi ke-etnis-an dalam pem belajaran sebagai sarana peningkatan "cultural intellegence"; (b) Knowledge Construction Process, berkenaan dengan prosedur bagaimana guru membantu siswa memahami materi pembelajar an dan bagaimana posisi individu dan ke-lompok etnisitas berpengaruh terhadap untuk memahami materi pembelajaran; (c) Prejudice Reduction; berkenaan dengan karakteristik sikap rasial siswa dan strategi yang 
dapat digunakan untuk membantu mereka menumbuhkan sikap demokratis; (d) Equity Pedagogy, berkenaan dengan upaya guru memfasilitasi berbagai kelompok etnis atau kelas sosial agar mendapat kesempatan yang sama dalam memperoleh pembelajaran; dan (e) Empowering School Cultural, berkenaan dengan proses merestrukturisasi kebudayaan dan organisasi sekolah agar siswa yang berragam etnis tersebut mendapat kesempatan yang sama dalam pendidikan dan pembelajaran (Aswandi, 2017)

Pendidikan multicultural merupakan strategi pembelajaran yang menjadikan latar belakang budaya siswa yang beraneka ragam digunakan sebagai usaha untuk meningkatkan pembelajaran siswa di kelas dan lingkungan sekolah. Kondisi yang itu dirancang untuk menunjang dan memperluas konsep-konsep budaya, perbedaan, dan kesamaan, dan demokrasi. Dengan demikian pendidikan multicultural adalah sebagai sebuah system pendidikan yang komplek yang memasukkan ide-ide dalam upaya mempromosikan pluralisme budaya dan agama serta persamaan social (Adibah, 2014).

Program Pencegahan Pemberantasan Penyalahgunaan dan Peredaran Gelap Narkotika (P4GN) sedang digalakkan di sekolah-sekolah yang dilakukan oleh Badan Narkotika Nasional Kabupaten Asahan. Kepala Bagian Pencegahan mengatakan bahwa setiap hari BNN Kabupaten Asahan terjun ke lapangan untuk melakukan sosialisasi dengan dampak narkotika bagi tubuh dan dapat merusak generasi bangsa. BNN Kabupaten Asahan melakukan tes urine di beberapa sekolah, jika hasil urine positif menggunakan narkotika maka akan dilakukan assessment kepada kepala sekolah untuk menindaklanjuti siswa yang positif mengkonsumsi narkotika. Siswa wajib melakukan rehabilitasi berjalan dengan didampingi orang tua dan pihak sekolah.

Siswa biasanya masih dalam tahap coba-coba, tetapi justru masih dalam tahap ini, siswa membutuhkan bimbingan khusus dari sekolah, BNN Kabupaten Asahan, dan juga keluarga. Jika siswa yang positif mengkonsumsi narkotika tidak diberikan bimbingan konseling secara berkala maka siswa yang dalam tahap coba-coba akan menjadi pemakai aktif narkotika.

Secara umum terdapat 5 tahap pengguna narkotika yaitu : (1) Tahap eksperimen (Tahap mencoba-coba), siswa pernah sekali atau beberapa kali mencoba mengkonsumsi narkotika. Motif ini biasanya karena rasa keingintahuan yang tinggi dan ingin mendapatkan pengalaman luar biasa seperti yang diceritakan teman-temanya; (2) Tahap rekreasi yaitu pemakaian sering dan menggunakan satu atau beberapa macam obat secara sendirian atau 
bersama-sama ; (3) Tahap situasional yaitu pemakain mengkonsumsi narkotika karena alas an tertentu seperti dalam keadaan stress; (4) Tahap abuse yaitu pemakaian sudah dalam jangka waktu yang lama dengan motif untuk mengurangi perasaan tidak enak terutama cemas, kekecewaan, kesedihan dan kemurungan; (5) Tahap adiksi yaitu penderita sudah sulit untuk menghentikan pemakaian narkotika (Guruh, 2013).

Upaya P4GN di Lingkungan pendidikan didasarkan pada (1) Undang-Undang Nomor 20Tahun 2003 Tentang Sistem Pendidikan Nasional; (2) Undang-Undang Nomor 35 Tahun 2009 Tentang Narkotika; (3) Keputusan Menteri Pendidikan Nasional Nomor 34 Tahun 2006 Tentang Pembinaan Prestasi Peserta Didik; dan (4) Keputusan Menteri Pendidikan Nasional Nomor 39 Tahun 2008 Tentang Pola Pembinaaan Kesiswaan (Guruh, 2013).

Di Indonesia, program pencegahan penyalahgunaan narkotika pada siswa telah dilakukan dengan aktivitas yang bertujuan untuk meningkatkan pengetahuan anggota masyarakat tentang penggunaan dan penyalahgunaan obat. Kegiatan dilakukan dengan memberikan penyuluhan melalui ceramah, pemutaran film, dan diskusi tentang penyalahgunaan narkotika khususnya bagi generasi muda.

\section{Moral Knowing Tentang Narkotika}

Moral Knowing terdiri dari 6 aspek yaitu (1) moral awareness; (2) knowing moral values; (3) moral reasoning; (4) decision making; (5) self knowledge; dan (6) perspective taking.Hasil menunjukkan bahwa Moral Knowing siswa tentang narkotika tergolong rendah $(38,00 \%)$ menjawab tidak pernah (Tabel 1).

Tabel 1. Persentase Moral Knowing Siswa tentang Narkotika

\begin{tabular}{|c|c|c|c|c|c|}
\hline \multirow[b]{2}{*}{ No } & \multirow[b]{2}{*}{ Indikator } & \multicolumn{4}{|c|}{ Kategori Moral Knowing Siswa tentang Narkotika } \\
\hline & & Selalu & Sering & $\begin{array}{l}\text { Kadang- } \\
\text { kadang }\end{array}$ & $\begin{array}{c}\text { Tidak } \\
\text { Pernah }\end{array}$ \\
\hline 1. & Moral Awareness & $10,00 \%$ & $12,50 \%$ & $62,50 \%$ & $15,00 \%$ \\
\hline 2. & Knowing Moral Values & $20,00 \%$ & $20,00 \%$ & $46,25 \%$ & $13,75 \%$ \\
\hline 3. & Moral Reasoning & $10,00 \%$ & $8,75 \%$ & $12,50 \%$ & $68,75 \%$ \\
\hline 4. & Decision Making & $2,75 \%$ & $3,75 \%$ & $3,75 \%$ & $90,00 \%$ \\
\hline 5. & Self Knowledge & $22,50 \%$ & $30,00 \%$ & $45,00 \%$ & $2,50 \%$ \\
\hline & Rata-rata & $14,05 \%$ & $11,00 \%$ & $37,00 \%$ & $38,00 \%$ \\
\hline
\end{tabular}

Pendidikan sebagai proses alih nilai mempunyai 3 sasaran utama yaitu: (1) pendidikan bertujuan untuk membentuk manusia yang mempunyai keseimbangan antara kemampuan kognitif dan psikomotorik di satu pihak dan kemampuan efektif di pihak lain; (2) dalam 
sistem nilai "dialihkan" juga termasuk nilai-nilai keimanan dan ketakwaan; (3) transformasi tata nilai yang mendukung proses industrialisasi dan penerapan teknologi (Muslich, 2011).

Moral knowing siswa perlu dibentuk agar siswa memiliki bekal pengetahuan sehingga karakter siswa yang telah terbentuk akan menjadi kebiasaan yang baik. Manusia memiliki kemauan yang bebas dan setiap orang harus mampu membuat pilihan moral yaitu memutuskan antara benar dan salah.

Narkotika sampai saat ini telah banyak merusak generasi bangsa terutama siswa baik di kalangan SMP maupun SMA. Pada siswa SMP seharusnya guru mampu memberikan pengarahan dan secara intens mengawasi siswa agar tidak terlibat dalam penyalahgunaan narkotika. Salah satu faktor yang berpengaruh terhadap penyalahgunaan narkotika adalah pengetahuan, dimana dalam suatu kondisi jika seseorang itu tahu bahwa hal yang akan dilakukannya akan berakibat buruk terhadap dirinya maka orang tersebut kemungkinan tidak akan melakukan hal tersebut. Peningkatan pengetahuan dapat dilakukan dengan cara penyuluhan. Hal ini sejalan dengan penelitian yang menyatakan bahwa ada peningkatan pengetahuan yang signifikan setelah pemberian penyuluhan (Badri, 2013).

Kenakalan anak setiap tahun selalu meningkat, apabila dicermati perkembangan tindak pidana yang dilakukan anak selama ini, baik dari kualitas maupun modus operandi yang dilakukan kadang-kadang tindak pelanggaran yang dilakukan anak dirasakan telah meresahkan semua pihak khususnya para orang tua. Fenomena meningkatnya perilaku tindak kejahatan yang dilakukan anak seolah-olah tidak berbanding lurus dengan usia pelaku (Nandang, 2010).

Perilaku tindak pidana yang dilakukan anak merupakan salah satu bentuk pengabaian sosial, sehingga mereka itu mengembangkan bentuk tingkah laku yang menyimpang. Anakanak yang melakukan tindak kriminal itu pada umumnya kurang memiliki kontrol diri dan suka menegakkan standar tingkah laku sendiri, disamping meremehkan keberadaan orang lain dan disertai unsur-unsur mental dengan objek yang subjektif yaitu mencapai satu objek tertentu dengan disertai kekerasan (Topo, 2011).

Proses pembentukan karakter adalah bagaimana anak-anak didik diberipengetahuan dan pemahaman akan nilai-nilai kebaikan yang universal (moralknowing) sehingga pada akhirnya membentuk beliefs. Anak-anak tersebut tidakhanya sampai memiliki pemahaman sajanamun sistem pendidikan yang ada jugaharus berperan aktif mendukung dan mengkondisikan nilai-nilai kebaikan tersebut sehingga semua anak mencintai nilai-nilai 
tersebut sebagai sebuah kebaikan untuk dianut (moral feeling). Setelah membentuk pemahaman dan sikap, maka dengan penuh kesadaran anak-anak akan bertindak dengan nilai-nilai kebaikan (moral behavior) yang dianut sebagai ekspresi martabat dan hargadiri (Fransisca dan Ajisuksmo, 2015).

Pentingnya pembinaan moral knowing siswa tentang narkotika adalah agar siswa terhindar dari pengaruh buruk narkotika, karena narkotika selain merusak tubuh tetapi juga dapat merusak syaraf yang dapat menyebabkan menurunnya prestasi siswa dan pada akhirnya siswa akan rusak secara pribadi dan juga akademik. Karakter pada dasarnya diperoleh lewat interaksi dengan orangtua, guru, teman, dan lingkungan. Karakter diperoleh dari hasil pembelajaran secara langsung atau pengamatan terhadap orang lain. Pembelajaran langsung dapat berupa ceramah dan diskusi tentang karakter, sedang pengamatan diperoleh melalui pengamatan sehari-hari apa yang dilihat di lingkungan termasuk media televisi. Karakter berkaitan dengan sikap dan nilai. Sikap merupakan predisposisi terhadap suatu objek atau gejala, yaitu positif atau negatif. Nilai berkaitan dengan baik dan buruk yang berkaitan dengan keyakinan remaja. Jadi keyakinan dibentuk melalui pengalaman sehari-hari, apa yang dilihat dan apa yang didengar terutama dari seseorang yang menjadi acuan atau idola seseorang (Darmiyati, 2011).

Implementasi pendidikan multicultural bisa dilakukan dengan menerapkan Program Pencegahan Pemberantasan Penyalahgunaan dan Peredaran Gelap Narkotika (P4GN) dengan strrategi pendidikan (1) memberi pemahaman yang benar tentang narkotika dan dampak negatifnya bagi pribadi dan sosial; (2) menumbuhkan kebiasaan untuk menjauhi narkotika; (3) menjadi contoh teladan bagi siswa; (4) pendidikan dan pembelajaran terintegrasi dan dialogis dengan menentukan strategi pembelajaran, subject matter, dan komponen pembelajaran lainnya untuk membentuk mindset siswa tentang dampak buruk narkotika (https://opiniaswandi.wordpress.com). P4GN yang terintegrasi dengan baik mampu meningkatkan moral knowing siswa tentang narkotika.

\section{KESIMPULAN}

Hasil kuesioner siswa tentang narkotika termasuk dalam kategori rendah. Siswa belum mampu menguasai dampak buruk narkotika dan tindakan preventif yang dilakukan siswa jika mereka mendapatkan tawaran untuk mencoba narkotika baik dari teman maupun orang asing. Lemahnya moral knowing siswa menunjukkan bahwa siswa kurang 
mendapatkan informasi mengenai narkotika dalam pembelajaran, jika Moral Knowing siswa tentang narkotika menunjukkan bahwa pengetahuan moral siswa sudah dalam kategori baik maka siswa mampu membentengi diri dari penyalahgunaan narkotika.

Implementasi pendidikan multicultural lintas budaya yaitu Program Pencegahan Pemberantasan Penyalahgunaan dan Peredaran Gelap Narkotika (P4GN) juga belum dilaksanakan oleh pihak sekolah sehingga pengetahuan siswa tentang penggunaan dan penyalahgunaan narkotika masih dalam kategori rendah. Sekolah memiliki peranan penting untuk membantu siswa memahami dampak narkotika, Keluarga, dan lingkungan juga memiliki peranan yang besar bagi perkembangan pengetahuan siswa. Intervensi dari pemerintah juga diperlukan terutama perhatian dari pihak BNN, Kepolisian, dan instansi lainnya yang dapat membantu mengurangi penyalahguna narkotika di kalangan siswa.

\section{UCAPAN TERIMA KASIH}

Ucapan terima kasih peneliti sampaikan kepada DRPM Ristekdikti berdasarkan Surat Keputusan Nomor 0045/E3/LL/2018 yang telah mendanai penelitian ini. Penulis mengucapkan terima kasih kepada SMP Negeri 1 Kualuh Hulu, Badan Narkotika Nasional Kabupaten Asahan, Sumatera Utara yang telah memberikan kesempatan kepada penulis untuk melaksanakan penelitian hingga selesai.

\section{REFERENSI}

Adibah, Z.I., 2014. Pendidikan Multikultural Sebagai Wahana Pembentukan Karakter. Jurnal Madaniyah. Vol 7 (2): 175-190.

Aswandi, 2017. Strategi dan Implementaasi Program Pencegahan Pemberantasan Penyalahgunaan dan Peredaran Gelap Narkoba (P4GN) Di Lingkungan Pendidikan. Opini. $\quad$ https://opiniaswandi.wordpress.com/2017/02/20/strategi-dan-implementaasiprogram-pencegahan-pemberantasan-penyalahgunaan-dan-peredaran-gelap-narkobap4gn-di-lingkungan-pendidikan/. Diakses 27 September 2018.

Badri, M., 2013. Implementasi Undang-Undang No. 35 Tahun 2009 Tentang Narkotika Dalam Pelaksanaan Wajib Lapor Bagi Pecandu Narkotika. Jurnal Ilmiah Universitas Batanghari Jambi, Vol 13 (3): 7-12.

BNN dan Puslitkes UI., 2011. Survei Perkembangan Penyalahgunaan dan Peredaran Gelap Narkoba pada Kelompok Pelajar di Indonesia

Darmiyati, Z., 2011. Pendidikan Karakter dalam Perspektif Teori dan Praktik. UNY Press, Yogyakarta. 
Chastanti, 2018. Konsep dan Pengembangan Pendidikan Karakter Pada Pembelajaran Biologi di SMA Kabupaten Labuhanbatu Utara. Jurnal Simbiosa. Vol 6 (2) : 95-103.

Chastanti dan Munthe, 2018. Analisis Moral Knowing Siswa Tentang Narkotika Dalam Implementasi Pendidikan Nilai Karakter. Jurnal Pelita Pendidikan, Vol 6 (3): 147152.

Fransisca dan Ajisuksmo, 2015. Keterkaitan Antara Moral Knowing, Moral feeling, dan Moral Behaviour pada Empat Kompetensi Dasar Guru. Jurnal Kependidikan. Vol. 45 (2): 211- 221.

Guruh, 2013. Strategi Pencegahan dalam Upaya Pencegahan dan Pemberantasan Penyalahgunaan Peredaran Gelap Narkoba (P4GN). Jakarta.

Muslich, M., 2011. Pendidikan Karakter: Menjawab Tantangan Multidimensional. Bumi Aksara, Jakarta

Nandang, 2010. Pembaharuan Sistem Pemidanaan Anak di Indonesia. Graha Ilmu, Yogyakarta.

Rauf, 2012. Faktor Penyebab Penyalahgunaan Narkoba di Kalagan Remaja. http://blogforilmu. Diakses 5 Juni 2017.

Rudi, Q., 2013. Narkoba Cederai Anak Bangsa.http://bnn.go.id. Diakses 5 Juni 2017.

Sholihah, 2013. Efektivitas Program P4GN Terhadap Pencegahan Penyalahgunaan NAPZA. Jurnal KEMAS. Vol. 9 (1): 153-159.

Topo, 2011. Kriminologi. Rajawali, Jakarta.

Wulandari, 2016. Implementasi Kebijakan Pencegahan Pemberantasan Penyalahgunaan dan Peredaran Gelap Narkotika (P4GN) Pada Kalangan Pelajar di BNNP DIY. Jurnal Kebijakan Pendidikan. Vol. V (5): 466 - 477.

Zubaedi, 2011. Desain Pendidikan Karakter Konsepsi dan Aplikasinya dalam Lembaga Pendidikan. Prenada Media, Jakarta. 